\title{
The Vyāghrī-Jātaka Known to Sri Lankan Buddhists and its Relation to the Northern Buddhist Versions
}

\author{
Matsumura Junko
}

\section{Introduction}

On the wall of a rock cave at Aluvihāra temple in Mātalē, Sri Lanka, among other jātaka stories and famous paintings describing tortures in hells, several painted stories of Bodhisattva, or jātakas, are found, of which no Pāli version is known. One of them is the wellknown story of Bodhisattva's body-sacrifice to a hungry tigress. The story is, however, not included in the canonical Pāli Jātaka collection, in which is found only a totally different story of the same name, the Vyagghajātaka (Ja no. 272), where Bodhisattva is a tree god. But the story which the people on this Theravāda Buddhist island know by the name 'Vyaggha-jātaka', or 'Vyāghrī-jātaka', is not the one in the Pāli Jātaka collection, but exactly the same story which is well-known and wide-spread among Northern (or Mahāyāna) Buddhists. This fact is the starting point of the present author's research for this article: How this story came to be known in Sri Lanka. The facts of the research may reveal some of the historical intercourse between Southern and Northern Buddhism, upon which, so far not much research has been pursued. Besides this, the story's version known on the island is not the sole one, but, as we discuss later, there seem to be several versions to be related to definite versions found in the Northern Buddhist texts.

\section{Versions of the tigress story}

The Bodhisattva body-sacrifice to a hungry tigress story (hereafter called 'the tigress story', or in Skt., 'Vyāghrī-Jātaka', as in Āryaśūra's Jātakamālāa) is related in several Northern Buddhist texts. The most well-known version may be the one in the Suvarna (pra)bhāsa-sütra (or the Suvarnaprabhāsottamasütra). For this sütra, there exist the Sanskrit text, the three translations in the Chinese Tripitaka, and the translations in Tibetan, Mongolian, Khotanese, and Uighur languages. However, it is beyond the scope of this article to examine and compare all these 
texts. In connection with the present article's theme, therefore, only the Chinese translations will be treated.

In the Xian-yu-jing 賢愚經, the so-called Sütra of the Wise and the Foolish, another famous version of the story is found. The main story of these two texts is essentially the same. However, the number of cubs to which the tigress gave birth differ, namely seven in the former and two in the latter. For the study of tigress story versions only these two have been attracting much interest. The number of cubs has been the most decisive characteristic, especially for art-historians, to identify the story's painted versions.

Beside those two texts, there are several other versions of the story which are divided roughly into two groups: texts in which Bodhisattva was Prince Mahăsattva, and texts in which Bodhisattva was a Brahman ascetic. In the following sections I will list the texts of these two groups with brief accounts of their contents.

\section{Versions in which Bodhisattva was Prince Mahāsattva (摩訶薩埵)}

3.1. The Suvarna (pra) bhāsa-sūtra（金光明經 tr. by Dharmakșema（量無讖）385-433 C. E., T16 no. 663, 353c22-356c21; 合部金光明經, a revised version of the former, completed in 597 C. E., T16 no. 664, 396c2-399c21; 金光明最勝王經, a new translation by Yi-jing（義淨） completed in 703 C. E., T16 no. 665,450 c22-454b25):

Bodhisattva was Prince Mahāsattva (摩訶薩埵), the youngest of three sons of King Mahāratha, the eldest being Prince Mahāpranāāa (or Mahābala), and the second, Prince Mahādeva. ${ }^{1}$ ) He saw a starving tigress with seven cubs and, out of compassion, he laid his body in front of the tigress. But, because of his power of loving-kindness, the tigress did not dare to eat him. So, having pierced his neck with a bamboo spike, he jumped down from a high mountain and lay dead in front of her. The tigress and her seven cubs could then eat his body and their lives were saved.

3.2. The Xian-yu-jing 賢愚經, or the Sutra of the Wise and the Foolish (compiled by Huijiao (慧覺) and others, based upon stories heard in the country of Gao-chang (高昌, Turpan, or traditionally called Turfan), 5th century, T4 no. 202, 352b19-353b16): The plot of the main story is very similar to the one in the Suvarna (pra)bhāsasütra. The only difference is that Prince Mahāsattva's father is Mahāratna, not Mahāratha, and the number of cubs is two. It also has a typical jātaka story structure, namely, a story taking place in the present (paccupannavatthu) and concludes with explanation of the connection of the characters in the main story with those in the present day story (samodhōna). 
3.3. The Fo-shuo-pu-sa-ben-xing-jing (佛説萻薩本行經, 4th-5th century C. E., translator unknown, T3 no. 155, 119a28-29):

摩訶薩埵太子時．第餓虎故放捨身命. When Bodhisattva was Prince Mahäsattva, he sacrificed his life for a hungry tiger (or tigress). There is no mention of the cubs.

3.4. The Pu-sa-ben-sheng-man-lun (菩薩本生綅論, ${ }^{2)}$ late 10th century to the early 11 th century C. E., T3 no. 160, 332b23-333b9): Except for a slight difference of the introductory narration, the content is apparently adopted from the Suvarna (pra) bhāsasütra.

3.5. The Fo-shuo-yao-xing-she-shen-jing (佛說要行捨身經, Tang dynasty, translator unknown; probably a compilation made in China, T85 no. 2895, 1415b6-7):

Having understood the truth of siunyată , Prince Mahāsattva offered his body to a hungry tigress and her seven cubs.

\section{Versions in which Bodhisattva was a Brahman Ascetic}

4.1. Āryaśūra's Jätakamālā or the Bodhisattvāvadānamāāa (4th 6th century C. E., Ed. H. Kern, 1-6):

Bodhisattva was born in a rich Brahman family and became an ascetic. When he was wandering in a forest accompanied by his disciple, Ajita, he saw a tigress that was about to devour her cubs out of intense hunger (number of cubs unstated). After having sent Ajita to look for food for the tigress, he threw himself in front of the tigress.

4.2. The Divyāvadāna (ed. P. L. Vaidya, 310, 29-312, 20):

Bodhisattva was born in a rich Brahman family and was named Brahmaprabha. He became an ascetic. When he and his two fellow ascetics saw a hungry tigress with two cubs, he gave his body to the tigress to prevent her from eating her cubs.

4.3. The Liu-du-ji-jing（六度集經, translated by Kan Seng-hui（康僧会,? 280 C.E.), T3 no. 152, $2 b 8-26)$ :

When Bodhisattva was practicing austerities on a mountain, he saw a hungry tigress nursing her cubs. Bodhisattva threw his body head-first into the mouth of the tigress. (Number of cubs unstated).

4.4. Kșemendra's Bodhisattvāvadānakalpalatā No. 51 (Rukmavatyavadāna, ed. Vaidya, II 316-319):

Bodhisattva was first born as a woman named Rukmavati. She cut her breasts off and gave them to a poor starving woman as food, and through the satyavacana done in front of god Sakra she was transformed into a man and became King Sattvavara. Then, in his next life, he was reborn as a 
Brahmin named Satyavrata and became an ascetic. When he saw a tigress, who had given birth to two cubs, about to eat them out of hunger, he gave his body as food to the tigress.

\section{The tigress story of the Fo-shuo-pu-sa-tou-shen-[yi]-e-hu-qi-ta-yin-yuan- jing（佛説菩嵼投身 [飴]餓虎起塔因縁經）}

In addition to the tigress story versions discussed above, there exists a very interesting and unique, in which Bodhisattva was a prince called Candanamati and later became an ascetic. The text is extant only in Chinese translation, but it is almost surely translated from a Sanskrit original, giving us a close look at a probable relationship with the Gandhāra region.

This text's name is the Fo-shuo-pu-sa-tou-shen-yi-e-hu-qi-ta-yin-yuan-jing（佛説菩薩 投身飴睋虎起塔因縁經, T3 no. 172, 424b5-428a12). According to the colophon, this text was translated by a monk, Fa-sheng, from Turfan in Northern Liang (北涼高昌國沙門法盛譯), so it may be assigned to ca. 440 C.E. A summary of the story is as follows:

Buddha once went to the kingdom of Gandhāra (乾陀越國) and there he related the following story: Nine kalpas ago, Bodhisattva was born as Crown Prince Zhan-tan-mo-ti (梅檀摩提; *Candanamati) of a great kingdom called Gan-tuo-mo-ti (乾陀摩提; *Gandhamati). His father, the King, was Gan-tuo-shi-li (乾陀尸利; *Gandhaśrī), and his mother, the Queen, was Cha-mo-mu-qu (差 摩目佉; *Kșemameghā?). The Crown Prince was fond of practicing charity, but, fearing to put his family into destitution by using up all the riches of the royal house, he secretly went to another kingdom called Pei-ti-she (裴提舍; *Vidiśā), where he sold himself as a slave to a Brahman for one thousand pieces of gold. These he then gave as alms to the poor. While he was collecting firewood on a mountain, he found a great amount of gośirșacandana (the best candana wood, said to cure all diseases), with which he then cured the king who suffered from leprosy. The king of Pei-tishe (Vidiśā) was very pleased, and after freeing the prince from slavery, sent him back to his native kingdom.

However, the prince again left the palace and went deep into the mountains to join a group of ascetics. One day, he saw a tigress with seven cubs, freezing in the snow at the bottom of a deep gorge. He told his teacher and five hundred fellow ascetics that he wanted to sacrifice his body to save the tigress and her cubs. Although his teacher tried to stop him, saying that he was still young and had much to learn, the prince replied that, in the distant past, he had made a vow to give his body a thousand times and had already done so nine hundred ninety-nine times in his former lives. This, then, was the final occasion to fulfill his vow. He climbed up to the top of a high precipice, threw himself off, and landed dead in front of the tigress. His parents, the Kind and Queen, built a stüpa there containing the prince's bones.

At the end of the story, the relationship of the characters in the past time to those in the 
present time is revealed, and the teacher in the group of ascetics is identified with Bodhisattva Maitreya. This is a noteworthy characteristic in connection with one of the Sri Lankan versions to be discussed below. This Chinese text also reports that the Dan and Xiang editions (丹胍本) have a sequel: The king (in the time of Buddha) built a great stüpa at the place, and it exists even to this day. At the east side of the stüpa, there is a temple compound and five thousand monks venerate the stüpa continually. Fa-sheng (法 盛, the translator of the text) himself saw that people from various countries who have an illness like leprosy or other diseases with no known cures always come to this stüpa to pay homage, and they are all cured. ${ }^{3)}$

The content of this text is, as seen above, very unique among the many versions of the tigress story. That Fa-sheng (法盛) seems to have visited the place and probably obtained the original Sanskrit text there, and also the fact that the name, Gandhāra, is mentioned in the text itself, gives proof that this version may have been the most popular one in 5 th century Gandhära. In addition, the text is endowed with features of masterly prose composition with a smooth narration vivid and sometimes even with humor. The present author would like to give only one example here: When the crown prince runs away to another kingdom to sell himself, the Queen, the mother, becomes half-crazed and reproaches the King:

“夫人罵曰：『由王慳苓，護惜錢財，不愛念子．今寧可以錢財為子身不？』王日：『吾失 在先, 今悔何及? 且共還宮, 保不失子。今悔何及? 且共還宮, 保不失子.” (T3 no. 172, 425c09-11)

The Queen curses the King saying; 'It is because you are stingy, grudging money and don't really love your son. Now what are you going to do for your son's life with the money?' The King answered: 'What's done is done. What use for regret? Now let's go back to the palace. I will certainly protect my son.'

Although in this case, the cause of argument is rather serious, the conversation is a quarrel that might be heard between any husband and wife.

\section{The Vyāghryavadāna in the Bodhisattvāvadānakalpalatā}

In addition to the version discussed above there is another unique version found in the Bodhisattvāuadānakalpalatā, No.95 Vyāghryavadāna (ed. Vaidya, vol.2, pp. 537-538) in which Bodhisattva was Prince Karuṇarekha, ${ }^{4)}$ not Prince Mahāsattva. In this version, emphasis is put on the story of the present time (paccupannavatthu), and, what is noteworthy, is that this story is more detailed than the one in the introduction of the same story in the 
Xian-yu-jing or the Sütra of the Wise and the Foolish (above 3.2.). However, the main story that it accompanies is totally different; Bodhisattva was a prince named Karunarekha, who gave his body to a tigress in order to prevent her from devouring her own two cubs out of intense hunger.

It is interesting that the Bodhisattvāvadānakalpalatā includes two totally different versions of the tigress story (cf. 4.4.)

\section{The Tigress Stories transmitted in Sri Lanka and their relation to Northern versions}

The paintings at Aluvihăra temple are apparently not of very old origin. But this fact does not mean that these jätaka stories were only recently introduced to Sri Lanka. The painting of the tigress story shows surprising correspondence with the version in the Divy $\bar{a}$ vadāna discussed above (4. 2.), because there are depicted two fellow ascetics of Bodhisattva and two cubs of the tigress. There is also concrete evidence in Fa-xian's travel record to India and Sri Lanka, the Gao-seng Fa-xian zhuan (高僧法顯傳 T51 no. 2085), that Northern or Mahāyānistic jātaka stories were known to Sinhalese Buddhists in the 5th century C. E. Fa-xian stayed at Abhayagirivihāra in Anurādhapura for about two years (ca. 410-412 C. E.), and during his stay he witnessed the Tooth Relic Festival. In his description of the festival we find the following passage:

佛齒常以三月中出之，未出前十日，王莊挍大象，使一辩説人著王衣服騎象上撃鼓唱言. 菩薩從三阿僧祇劫作行不惜身命. 以國城妻子及挑眼與人 割肉貿鴿 截頭布施 投身觛 虎 不愘髓腦. 如是種種苦行爲衆生故成佛。(T51 no. 2085, 865a20-25) ${ }^{5}$ )

Here, not only the tigress story but also the story of cutting off one's flesh to save the life of a dove (the Mahāyāna version of the Śibi-jātaka) and the story of cutting off the head to give it as alms (the King Candraprabha Jātaka, for which the Pāli text is so far unknown) are mentioned. Also, the period of Bodhisattva's past lives to fulfill all pāramitās to become a Buddha is here said to be three asankhyeya-kalpas, a period commonly said in most Mahāyāna Buddhist literature, while in the Theravāda tradition it is usually said to be four asañkhyeyas and a hundred of thousand kalpas.

Actually, on his way to India, Fa-xian visited the place where Bodhisattva sacrificed his body to save a tigress:

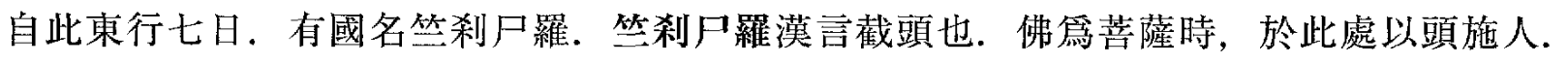


故因以鷂名．復東行二日至投身餧餓虎處。此二處亦起大塔．皆衆寶挍飾．諸國王臣民競 興供盖．散華然燈相繼不絶．通上二塔彼方人亦名爲四大塔也． $(\mathrm{T} 51 \text { no. } 2085,858 \mathrm{~b} 6-11)^{6)}$

As discussed above, Fa-sheng (法盛) also visited the same place only about 20 years later than Fa-xian (法顯). ${ }^{7)}$ Therefore, the story that Fa-xian knew may be most probably the same version of the Pu-sa tou-shen fan e-hu qi-ta jing 菩薩投身飯餓虎經, or the Foshuo pu-sa tou-shen yi e-hu qi-ta yin-yuan jing 佛説菩薩投身飴諓虎起塔因縁經（ $\mathrm{T}$ no. 172) translated into Chinese by Fa-sheng, and not the famous version in the Suvarna (pra) bhāsasutra; this is because in the T no. 172 version, the stūpa containing Bodhisattva's bones was built at the place where Bodhisattva sacrificed his body, and at the time of Faxian and Fa-sheng, people believed the stūpa near Taxila (probably at Mardan) was that one, while in the Suvarna (pra) bhāsasutra version, Buddha relates the story at the request of the Bodhi tree under which he attained enlightenment. The stüpa appears from the earth when Buddha starts the sermon and it disappears at its end. About 200 years later, when Xuan-zang (玄牀) visited the same place, there was still that same stūpa, but the cloister was almost deserted. This may be the reason why Xuan-zang connected the place with the Suvarna (pra) bhāsasūtra version of the story.

In Sri Lanka, another painting of the tigress story is found on the outside wall of an image house at Ruvanvälisäya in Anurādhapura. In this painting, however, there are depicted neither the two brothers nor the cubs. We may say that this painting corresponds to the version in the Fo-shuo-pu-sa-ben-xing-jing (above 3.3.)

Finally, there is a written text of the tigress story in Sri Lanka: A Wesleyan missionary, Robert Spence Hardy, reported the story in his Manual of Buddhism published in 1853:

"The next birth received by Bodhisat was as a Brahman, in the village of Dāliddi; and on account of the great beauty of his person he was called Brahma. As sixteen years of age he had read the three Vedas, Irju, Yaju, and Sāma, and was acquainted with all the sciences. Near the rock of Eraka, but then called Munda, he became an ascetic, and had 500 followers, of whom the Bōdhisat who will one day become Maitri Budha was the chief. One day, when this (!) disciple and Brahma were wandering about the forest to gather fruits for their sustenance, they saw near the rock a tigress that had some time before brought forth, and was then suffering from hunger. Brahma, on seeing this, reflected again on the evils of existence, and sent his disciple if he could find any bones of offal that they could give to the tigress to appease its hunger. During his absence, Brahma remembered that it was only by the birth of a Budha that these evils could be removed; and calling to mind that resolution he had previously formed, he reflected that in order to the attainment of this great object it 
would be necessary for him to give in alms, many times, his own heads, eyes, wives, and children. Then exclaiming, "May I by this become a Budha" he placed himself in the way of the tigress, that by giving his flesh he might preserve its life and that of its little ones. When the animal perceived him, it bounded from the rock to the place where he stood, seized him, and tore him in pieces. By the power of the merit arising from this act he was born in a devva-lokka."8)

This story is, according to its author, based upon the Saddharmarainakaraya, the 15th century Sinhalese work written by Dharmadinna Vimalakirti. In this story we can see the resemblance to the Jätakamālă version, in which Bodhisattva wandered in the forest accompanied by only one disciple, Ajita. But it also shows resemblance with the T no. 172 version, in which Bodhisattva joined the group of 500 ascetics and their leader is identified with the future Buddha Maitreya. However, this version is also different from the two painted story versions that the present author saw in Sri Lanka.

\section{Conclusion}

As we have seen above, we know still very little about the actual Theravāda Buddhist tradition. Although it is generally believed that Mahāyāna Buddhism was denied and all Mahāyāna scriptures were destroyed by religious reform undertaken by King Parākramabāhu the Great in the 12th century in Sri Lanka, some of the Northern or Mahāyāna traditions once introduced on the island have been transmitted in various ways. It is very important to search for those elements both in art and in texts in order to understand the reality of Sinhalese Buddhism, or even to understand how the literal tradition was transmitted over centuries. To discover these elements, it is important, on the one hand, to investigate the great mine of Sinhalese medieval (11th-15th centuries) Buddhist literature as well as the post-canonical Pāli literature of the same period, since in that age the Sinhalese Buddhist scholar-monks were very active and produced many works. It is in these that the old traditions of the island still alive at that times. On the other hand, also important, as the present author has shown by example, is a more detailed study of the texts belonging to the Northern tradition, especially the texts only surviving in Chinese translations along with the study of Pāli or Southern Buddhist texts. Needless to say, to get the complete picture of Sinhalese Buddhism we must go back into history, into its art and literature, a huge task for which the concentrated collaboration of scholars in the allied fields of archeology, art history and linguistics is to be greatly intensified and deepened. 
1) $\mathrm{T} 16$ no. $663,353 \mathrm{c} 22-356 \mathrm{c} 21$; = no. 664, 397a6-399c21; no. 665, 450c23-454b25. For the Skt. text, see Nobe1, Johannes (1937), Suvarnaprabhāsottamasūtra, Das Goldglanz-sūtra: Ein Sanskrittext des Mahāyāna-Buddhismus nach den Handschriften und mit Hilfe der Tibetischen Übersetzungen (Leipzig: Otto Harrassowitz), pp. 201-240. 2 ) For this Chinese text, advocated as a translation of Āryaśūra's Jätakamālā, see the famous article by Brough, John (1964), "The Chinese pseudo-translation of Āryaśūra's Jātakamālā," Asia Major, new series XI. 1, pp. 27-53 (= Hara Minoru and Wright, J.C. (1996) ed., Collected Papers (London: School of Oriental and African Studies), pp. 217-243. 3) The abridged version is found in the Chinese Jing-lï-yi-xiang（經律異相 T53 no. 2121), compiled by Bao-chang (寶唱) and other monks in 516 C. E. The tigress story is found in Scroll 13, 162a22-c23 in which Bodhisattva was Crown Prince of the Kingdom of Gan-tuo-shi-li (乾陀尸利; *Gandhaśri??), and it is stated that the story is taken from the Pu-sa tou-shen fan e-hu qi-ta jing (菩薩投身飯餓虎經), which obviously indicates the Fo-shuo pu-sa tou-shen yi e-hu qi-ta yin-yuan jing（佛説菩薩投身飴餓虎起塔因縁 經). However, the Jing-lii-yi-xiang adopts only the latter part of the original text corresponding to T3 $426 \mathrm{c} 23-427 \mathrm{c} 19$, i.e. the story of the prince's sacrifice of his body to the tigress. 4) According to the recent research made by Okano Kiyoshi, the prince's name is Karunarenu. See Okano, Kiyoshi (岡野潔) (2009), “Avadānakalpalatā chap. 94-97 and SMRAM chap. 23: Edition and Japanese Translation of Yaśomitra, Vyāghrī, Hastin and Kacchapa stories” (Avadānakalpalatā 94-97 章 と SMRAM 23 章-Yaśomitra, Vyāghrī, Hastin, Kacchapa の校訂・和訳一), South Asian Classical Studies (南アジア古典学), No. 4, pp.95-177。 5 ) Cf. Legge, James (1886), A Record of Buddhistic Kingdoms: Being an Account by the Chinese Monk Fa-Hien of his Travels in India and Ceylon (A.D. 399-414) in Search of the Buddhist Books of Discipline, translated and annotated with a Corean recension of the Chinese text (Oxford: Clarendon Press; reprint, New York: Paragon Book Reprint Co., 1965), p. $105 . \quad 6$ ) Cf. Legge, op.cit., p. 32. Here Legge also mentions the tigress story in Spence Hardy's book in fn. 2. Cf. fn. 10 below. 7 ) As for Fa-sheng's biography and his travel account to India and Sri Lanka, see Ochiai, Toshinori (落合俊典) (2001), “Shaku Hōjō sen Rekkokuden oboegaki [Notes on Fa-shen's Li guo chuan]”（釈法盛撰『歴国 伝』賞書), Fs. Prof. Ishigami Zennō (石上善應教授古稀記念論集), Tokyo: Sankibō busshorin, Vol. 2, pp. 29-43. 8 ) Hardy, Robert Spence (1853), A Manual of Buddhism in its modern development (London: Partridge \& Oakey; Repr. Chowkhamba Sanskrit Studies Vol. LVI, Varanasi, 1967), pp. 91f. Cf. von Hinüber, Oskar (1998), Entstehung und Aufbau der Jātaka-Sammlung: Studien zur Literatur des Theraväda-Buddhismus I (Stuttugart: Franzsteiner, 1998), pp. 114f. and fns. 343 and 344.

(The research for this article was supported by the Grant-in-Aid for Scientific Research (B) No. 21320015 from JSPS)

〈Key words〉 Vyāghrījātaka (投身戝虎), Sri Lanka, Gandhāra, Fa-xien (法顕), Fa-sheng (法盛) (Professor, International College for Postgraduate Buddhist Studies, Ph.D.) 